\title{
Host Community's Social and Cultural Capital for Ecotourism Development in Indonesia
}

\author{
E. Rachmawati ${ }^{1}$ \\ ${ }^{1}$ Department of Forest Resources Conservation and Ecotourism, Faculty of Forestry, Bogor \\ Agricultural University (IPB), Po Box 168, 16680, Bogor, West Java, Indonesia
}

\begin{abstract}
Social relationships and interactions that build tourism resources and products are critical to the satisfaction of tourists. This article described that social capital within the host community living around a tourism destination that influenced the ecotourism development in that specific site. The host community's social capital was also influenced by the community's cultural capital. The elements of the social system that had to be considered in West Java community were interpersonal trust in sentimental elements and norms. However, the research conducted by Baksh et al (2013) at Tambak Sari Village (East Java Province) showed that there was a relationship between networking and ecotourism development. Surprisingly, trust and norms had no relationship with ecotourism development. West Java and Central Java communities had different social and cultural conditions. The Javanese community is famous for their social class system, and their general characteristic tends to be introverted. Meanwhile, Sundanese people (in West Java) are softer, more likely to give in, not ambitious in the competition and more open to new comers. The research result indicated that the development of ecotourism should consider the social and cultural capitals that are hold by the community.
\end{abstract}

\section{Introduction}

The success of tourism development in a certain region requires a balance between environmental, economic, social, and cultural aspects that create a sustainable tourism [1] [2]. Community members, as one of social aspects, have a vital role in encouraging ecotourism development in their region, and their participation and involvement are critical to the process [3]. It has been hypothesized that high levels of social cohesion, cooperation, and coordination are instrumental in ensuring successful ecotourism development. Social capital-constructed upon common norms, trust, and networks-has been suggested as the 'missing link' in the development and has become a focus of policy, practice, and research in recent years.

Social capital can be defined as networking and cooperation among local people who are able to facilitate the community to find solutions regarding certain problems they encounter. Prusak [4] explains that social capital refers to a set of active relationship among human beings. The important aspect encompasses trust, understanding, and norms and behaviour. Such aspects have been identified as factors to build a society in a network and enable cooperation among the members of the society. 
Social relationship and community participation are the social capital which needs to be taken into account in the development of tourism sector. Social relationship refers to interaction among individuals formally and non-formally, which results in the acceleration of development in certain areas. Bourdieu states that there are three fundamental capitals: economic, cultural and social. And they are related to one another [5].

Indonesia has not only great natural resources potential for tourist destinations, but also diverse cultures originating from about 300 ethnic groups. Certainly, the rich natural resources can be developed as ecotourism destinations. Based on TTCI Index, among Asia-Pacific countries, Indonesia ranks the sixth for excellent natural resources with its amazing biodiversity. Indonesia is also rich in cultural resources (ranked 38th) with 10 World Heritages of cultural sites [6]. However, the development of ecotourism is still far from satisfactory [6]. This is probably due to the available research data and information on ecotourism activities which still put the emphasis on the physical and biological aspects of the country. Very few researchers tried to look into the existing social aspects, especially those related to the community.

The goal of ecotourism is to improve the welfare of the local community and to protect the destination sites. However, the results of several researches indicated that the majority of the local people still had not felt the positive impacts of ecotourism, where only a small proportion of the community had received the benefits economically, not to mention the degradation of cultural identity and traditional knowledge due to outside influences [7-10]. One important factor that commonly hampers the success of ecotourism development is a lack of participation in ecotourism management due to having insufficient and skills [9, 11-12].

Therefore, to ensure the success of ecotourism development, there should be a conscious effort to improve understanding and knowledge of the community socioeconomic and cultural conditions [13-14] by empowering the community through sharing such things as economic, psychological, social and political aspects [15] so as to increase their participation [16].

\section{Methodology}

Social Capital of West Java Area was examined by conducting in-depth interviews with the stakeholders involved and Focus Group Discussion (FGD) method with the surrounding community members to identify the elements of social capital that influenced the ecotourism development in the area. There were 131 respondents, consisting of government official (village head), community elders, non governmental organization, tourism entrepreneurs, and the community members who were not involved in tourism activities. The social system condition was described using Causal Loop Diagram to see the connection between causes and consequences in the social system elements. The result of the research was compared with the result of the research of Social Capital in the Development of Ecotourism at Tambaksari Village (East Java) which was conducted by Rukavina Baksh et al [17]. This served as comparison of the writer research at Gunung Sari and Gunung Bunder Village (West Java).

Baksh et al designed a questionnaire with four variables related to social capital in tourism development, namely, networking, trust, norm, and participation in ecotourism development. The questionnaires were distributed to 170 respondents in Tambaksari Village. The reliability and validity of the variables in this study were tested using Confirmatory Factor analysis [18]. Structural equation modelling (SEM) techniques were used to estimate the models of causal relationship among social capital variables of the ecotourism development which were implemented by using AMOS 6 . 


\section{Data Analysis and Discussion}

\subsection{Gunung Sari and Gunung Bunder 2 Village (West Java)}

\subsubsection{Study Location}

These two villages are located near a tourism destination called Mount Salak Endah (GSE) Area, which offers eight attractions that have been intensively managed. Gunung Sari village community consists of three groups, namely indigenous community members, veterans, and migrant groups. Veteran community is a group of people who first opened the land in the area now called Kampung Lokapurna, while the migrant are the people who live in Kampung Lokapurna after the tourism activities in the region began to develop. Veteran community are the people who live in Kampung Lokapurna, where most of the tourism attractions (62.5\%) are located. Gunung Bunder 2 village is mostly occupied by indigenous community.

\subsubsection{Social and Cultural Capital for Ecotourism Development}

\section{Trust}

The mechanism involving stakeholders in the two villages was influenced by trust $(67 \%)$ and the ability to monitor the work result (33\%). Mount Salak Endah community members who were involved in the ecotourism development came from different backgrounds, but they had the same interest as far as economic expectation was concerned. Therefore, one major thing that could be done was to build trust between the stakeholders. Trust is necessary for the development of an activity in a condition where the people involved could not rely on formal legal institutions [19].

\section{Norms and Social Sanctions}

The social system of nature-based tourism development in Gunung Salak Endah area does not have norms that can regulate stakeholders behavior. This is because there are no sanctions in case of violations against the norms. Gunung Salak Endah community, especially the people who live in Kampung Lokapurna, Gunung Sari village, came from different backgrounds, so that they adopted diverse values and norms as evident in their behavior. In other words, there should be clear norms that can control and organize stakeholders behavior for the ecotourism development in Gunung Salak Endah area.

Unlike Gunung Salak Endah, norms clearly exist in the villages of Gunung Sari and Gunung Bunder 2, because the people come from the same cultural cluster (Sundanese Culture) and the majority of the population are Muslims. However, so far, the norms prevailing in the ecotourism development area are powerless. The violators receive only light sanctions, very often in the form of ridicule and the like.

Actually, the norms that prevail in these two villages impose sanctions on the violators, but they are never implemented, because no stakeholders perceive that they have the authority to make and apply the norms to regulate stakeholders behavior in nature-based tourism development. Based on the results of interviews, the stakeholders would seriouly obey the norms if severe sanctions were imposed on (mainly formal legal norms), for example, in form of imprisonment. In nature-based tourism development, there are legal norms with heavy sanctions, but they are not well implemented, making the stakeholders involved in the development of nature-based tourism able to do anything as they wish without the fear of getting any sanction. As a result, the social structure cannot function as a basis to serve as social discipline and control. 
In Sundanese, 'sesepuh', who is a person or a group of elders, have the power to determine the customs in the community, which may include several villages. The elders are usually the descendants of the village founder and they are often considered to have magical authority. They always maintain the harmony in the community using customary provisions handed down by their ancestors, including determining people's participation in rural development efforts, mutual assistance, agricultural rituals, life cycle and the launch of village government.

\section{Community Participation}

The stakeholder's involvement mechanism in these two villages was based on relationship (relatives or family $74 \%$ and friendship $26 \%$ ). The area manager and other stakeholders who own a tourism bussiness in this two villages always find the local people they have already known if there are job opportunities. The people will then recommend their family or closed friends to join. This causes the local people who do not have any relation with the ones who are already involved in tourism activities, do not have a chance to participate. Another case in Gunung Bunder 2 village, the area manager recruited the local people who used to disturb tourism activities in the beginning (in Indonesian, they are called "preman") to decrease or even stop their disturbing behavior. Family relationship and friendship can support social organization development and better social networking quality, especially if well managed. Another barrier for community involvement was less dissemination of information related to tourism bussines opportunities. The area managers or bussiness owners usually give information to the people they have already known or to the people who frequently come to the area. They would not announce it to all community members or government officials (village head and village official).

\section{Networking}

The occurrence of negative interaction will hamper the development of cooperation between individuals from differing groups. In addition, the frequency and intensity of interaction which are greatly influenced by visitation have also hampered a better interaction development. It is because the communication only occurs when they are serving visitors, and there are no coordination and communication to address other problems related to nature-based tourism development. One of the social capitals needed to support the success and sustainability of nature-based tourism development is the existence of social networks between stakeholders involved [19] [20] [21] [22] [23]. The factor which influenced the development of social networks is good relation between the stakeholders involved [23].

Social networks at GSE showed the relation development between individuals [21] involved in the nature-based tourism development. The stakeholders involved in the nature-based tourism development at GSE had not developed social networks yet as shown by the primary positive interaction only occurred to individuals joining the same group, while most interactions between individuals from different groups, which could support social networks development, were secondary (indirect) or even negative interactions, which led to competition and disintegration. This would drive cluster formation in the nature-based tourism which evetually weakened the existing social networks.

Negative interactions occurred more at Gunung Sari Village area. Besides, the greater the number of stakeholders involved, the higher the immigration rate would be, which had surely become an influencing factor. The large number of people who moved in to the village had weakened the family bonds between community members and influenced the long-existed social structure [21]. It was a condition which further hampered social networks development in the nature-based tourism at GSE. 


\subsection{Tambak Sari Village (East Java) [17]}

\subsubsection{Study Location}

The study was carried out at Tambaksari Village, Pasuruan Regency, East Java Province, Indonesia. The village is located at the slope of Mount Arjuno, making ecotourism the best tourism concept to develop in order to preserve the whole area. The village is divided into four smaller areas (locally called Dusun) with their own uniqueness. The first area, Dusun Krai, is famous for its milk production. The second area, Dusun Ampelsari, is famous for its traditional art. The third area, Dusun Gunung Malang, is well-known for its coffee production. The last area, Dusun Tambak Watu, is well-known for its historical and archaeological sites at the slope of Mt. Arjuno. The uniqueness has made Tambaksari Village rich in ecotourism attractions.

\subsubsection{Social and Cultural Capital for Ecotourism Development}

\section{Trust}

The result indicated that there was no relationship between Trust and Ecotourism Development. Trust variable did not directly affect ecotourism variable, yet it had to work through networking variable and participation variable. Trust should be built through cooperation or networking among and participation of the local community themselves. However, people sometimes do not trust each other, and this happened in Tambaksari Village in which the local community did not trust other parties, resulting in the weak ecotourism development. In addition, the human resources in Tambaksari village had not been completely empowered. Many villagers did not understand the whole concept of ecotourism development. Local community participation was limited to representation. The villagers did not believe in the prospect of ecotourism in the future, as seen from the low participation in the development of ecotourism. This situation slowed down the development of ecotourism. Therefore, participation and networking among the local community need to be improved in order to develop trust to support ecotourism development. In other words, the better the trust among the local community, the better the networking and participation of the villagers in the development of ecotourism in Tambaksari village.

\section{Norms}

The result revealed that there was no direct correlation between norms and ecotourism development. Norm variable did not directly affect the development of ecotourism, and if it did, the effect could be seen indirectly through networking variable or participation variable. Supposing that the norms of the local people of Tambaksari Village were quite strong, they would not make any betterment in the development of ecotourism in that village, and the vice versa. Norms, however, would help to strengthen networking and participation, which indirectly would help to improve the development of ecotourism in Tambaksari village. According to Fukuyama [26], norms are formed spontaneously, tend to be informal, meaning that norms are neither written nor announced. Rules that are called as norms are beliefs upon which the local people of Tambaksari village lean the good expectation of their lives. These rules are not written but have been there in the village since a long time ago. However, formal rules are still indispensable in the development of ecotourism to protect the natural diversity and to minimize the bad effects of ecotourism towards the environment. Such rules may cover the rules on the use of water, waste management, energy conservation, bird hunting, and the protection of old statues in Tambaksari village. 
The results indicated that there was a significant correlation between Community Participation and Ecotourism Development. That community participation affected ecotourism development was manifested through the involvement in planning, decision-making, action/implementation, utilization, and evaluation. This study revealed that the development of ecotourism in Tambaksari village had already involved the local community, for example, by providing home-stays or becoming tour guides.

Of the four variables on social capital, i.e. networking, trust, norms, and participation, it was found out that networking was the most dominant variable which affected the development of ecotourism, making it the strongest social capital which directly affected the development of ecotourism in Tambaksari village. Nevertheless, the strength and quality of networking in that village should be continuously improved.

\section{Networking}

Based on the results of the analysis, there was a significant relationship between Networking and Ecotourism Development. In Tambaksari Village, continuous communication was conducted through meetings among the villagers, their membership in the organizations, and exchanging information among them. Through the meetings, information was exchanged and shared among the people to help make final decision and take action. Actions and agreements are manifested through the ecotourism management by the local people themselves.

The importance of networking, as stated by the respondents, was seen in the relationship between the local community and the non-government organizations. This represented the existence of organizational relationship and bound between the local people of Tambaksari Village and the nongovernment organizations which, in turns, would strengthen the networking for the success of ecotourism development in that village. In this sense, the non-government organizations (NGOs) voluntarily cooperated with the villagers in the development of ecotourism, and the local people had to build good relationship with NGOs as the volunteers in ecotourism development. Sproule [16] states that NGOs can play an important role as a source of human resources for technical assistance and a source of funding. Other than the non-government agencies like these, community-based ecotourism should also seek support from the government. The role of the government in the development of ecotourism is as the decision maker and patron for the local community [24][25]. The government policy in conservation and preservation of nature, natural resources, natural diversity, and cultural identity is the major support for the sustainability of ecotourism. Both local and central government can do this [26].

\section{Recommendation}

To improve the chances of success in the development of ecotourism in the region, the social and cultural conditions of the local community should be well considered, because every community has its social aspects and particular cultures. So the management and or empowerment approach can be adapted to suit the community condition.

\section{Conclusion}

All the elements of social capital influence the ecotourism development in a region, both directly and indirectly. It greatly depends on the socio-cultural condition of the local community. 


\section{References}

1. C.R. Goeldner, B. Ritchie, R.W. McIntosh . Tourism: Principle, Practice, Philosophies. (John Wiley \& Sons, Inc, Canada, 2000)

2. J.V. Milic, S. Jovanovic, B. Krstic, Sustainability Performance Management System of Tourism Enterprises. FACTA UNIVERSITATIS. Series: Economics and Organization 5, 2 (2008)

3. (TIES \& UNEP). The International Ecotourism Society \& UNEP . The Components of Succesfull Ecotourism. http://www.pnuma.org/eficienciarecursos/documentos/ecotourism2.pdf

4. L. Prusak. In Good Company: How Social Capital Makes Organization Works. (Harvard Business School Press, Harvard, 2001)

5. P. Bourdieu. The Forms of Capital', in Richardson, John G., ed., Handbook of Theory and Research for the Sociology of Education (Greenwood, New York 1986)

6. (WEF) World Economic Forum. The Travel \& Tourism Competitiveness Report 2013: Reducing Barriers to Economic Growth and Job Creation. (World Economic Forum, Geneva, 2013)

7. E. Rachmawati. Dampak Ekonomi Kegiatan Pariwisata Alam di Taman Nasional Gunung Gede Pangrango terhadap Masyarakat Sekitar Kawasan. J. Htn. Trop 1, 1 (2006)

8. E. Rachmawati, A. Sunkar, E.K.S.H. Muntasib. Interaksi Sosial Masyarakat Dalam Pengembangan Wisata Alam. Forum Pascasarjana 34, 1 (2011)

9. M.J. Walpole, H.J. Goodwin. Local economic impacts of dragon tourism in Indonesia. Ann. Tourism Res. 27 (2000)

10. A. Sunkar, E. Rachmawati, R. Cereno. . Ecotourism Development in Brunei Darussalam, Indonesia, Lao PDR, Myanmar, Singapore and Philippines. Kim, Seong-il, Mihee Kang and Dian Sukmajaya (eds.). Opportunities and challenges of ecotourism in ASEAN countries. Seoul, Jungmin Publishing Co. 278pp. (2013)

11. A. Zambrano, M. Angélica, N. Eben, Broadbent, H.D. William. Social and environmental effects of ecotourism in the Osa Peninsula of Costa Rica: the Lapa Rios case. J. Ecotourism 9, 1 (2010)

12. H. Zhang, S.L. Lei., 'A structural model of residents' intention to participate in ecotourism: The case of a wetland community'. Trsm Mngmnt 33 (2012)

13. E. Guiterrez, K. Lamoureux, S. Matus, K. Sebunya. Linking Communities, Tourism \& Conservation; A Tourism Assessment Process. (Conservation International and The George Washington University, 2005)

14. M.E. Wood. Ecotourism: Principles, Practices \& Policies for Sustainability. (United Nationas Environment Programme - Division of Technology, Industry and Economics., 2002)

15. Scheyvens. Ecotourism and the Empowerment of Local Communities. Trsm Mngmnt, 20 (1999)

16. S. Pratiwi S. Local Community Participation in Ecotourism Development: A Critical Analysis of Selected Published Literature. J. Manajemen Hutan Tropika XII, 2 (2006)

17. R. Baksh, Soemarno, L. Hakim, I. Nugroho. Social Capital in the Development of Ecotourism: A Case Study in Tambaksari Village Pasuruan Regency, East Java Province, Indonesia. J. Basic and Applied Sci Res 3, 3 (2013)

18. A. Ferdinand.. Structural Equation Modeling dalam Penelitian Manajemen.(UNDIP, Semarang, 2000)

19. F. Lyon. Trust, Networks and Norms: The Creation of Social Capital in Agricultural Economies in Ghana. World Dev.28, 4 (2000)

20. B. Hadley. Partnership, Social Capital and The Successful Management of Small Scale Cultural Festival: A Case Study of Hobart's Antartic Midwinter Festival. Proceedings Re-eventing the 
Ciy-Events as Catalysts for Change, Fourth International Even Research Conference (University of Technology Sidney and Victoria University, Melbourne, 2007)

21. T. Patterson, T. Gulden, K. Cousins, E. Kraev. Integrating Environmental, Social and Economic Systems: A Dynamic Model of Tourism in Dominica. Ecological Modelling 175 (2003)

22. A. Spellerberg. Framework for the Measurement of Social Capital in New Zealand. (Statistic New Zealand 2001)

23. B. Weiler, J. Laing. Developing Effective Partnerships for Facilitating Sustainable Tourism Associated with Protected Areas. (The Sustainable Tourism Cooperative Research Centre - The Australian Commonwealth Government, 2009)

24. I. Nugroho.. Ekowisata dan Pembangunan Berkelanjutan. (Pustaka Pelajar, Yogyakarta, 2011)

25. M. Paulina, D.G. Dettori, A. Paba.. Life cycle of agro touristic firms in Sardinia. Tourism Management 27 (2006)

26. K.W. Sproule. Community-Based Ecotourism Development: Identifying Partners and Process. Wildlife Preservation Trust International (1996) 